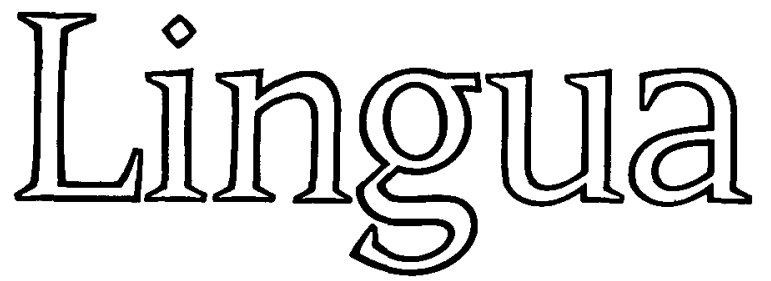

International Review of General Linguistics

Editors:

A. J. B. N. Reichling, Amsterdam

E. M. Uhlenbeck, Leyden

W. Sidney Allen, Cambridge
Executive Editors:

S. C. Dik, Amsterdam

J. G. Kooij, Leyden

Founded in 1947 as an independent forum for students of language. LINGUA has developed into one of the world's more important linguistic periodicals.

Each bi-monthly issue contains current work on a variety of linguistic topics. Although these articles are written from different points of view, they are required to contain such general theoretical implications as to be of interest to any linguist, whatever his own specialization.

No particular linguistic theories or scientific trends are favoured; scientific quality and scholarly standing are the only criteria applied in the selection of papers accepted for publication.

Besides papers, LINGUA publishes review articles surveying developments in the various fields of linguistics, as well as occasional discussions. A considerable number of pages in each issue are devoted to critical book reviews. In addition, a 'Publications Received' section, systematically ordered by topic, gives a useful account of recent linguistic publications.

LINGUA is published in two volumes per year, comprising six bi-monthly issues. The subscription price for 1974 , Volumes 33 and 34 is Dfl. 146.00 or US $\$ 58.50$ including postage and handling. Sample copies are available on request. 


\section{the human context}

Editor Responsible:

Paul A. Senft, 17 Platt's Lane, London, NW3 7NP, U.K.

'the human context' explores the philosophical assumptions and the methodology of the human sciences (the different fields of psychology, sociology and anthropology). It aims at a critical dialogue between different orientations in philosophy itself and at a confrontation with science. The total yearly volume of the periodical is in excess of 600 pages and is published in three issues annually, with original contributions in full translation from and into English, French, German, Spanish and Italian.

Articles

VOLUME VI, NO. 1, 1974

GERARD RADNITZKY: On the Crucial Role of Preconceptions about the Subject Matter in Scientific Research

ANTHONY DE REUCK : Controlled Communication: Rationale and Dynamics

MITCHELL GINSBERG : Action and Communication

J. P. COULTER: The Ethnomethodological Programme in Contemporary Sociology

G. BENEDETTI: The Irrational in the Psychotherapy of Psychosis

ROBERT D. ROMANYSHYN: Psychotherapy: A Dialogue of Faith and Power

JOSEPH F. RYCHLAK: The Misplaced Dialectic in the Dialogue of Faith and Power

MICHAEL G. PICARDIE: A Metaphysical Order in Psychiatric Work

ALEX COMFORT: On Sexuality, Play and Earnest

MIGUEL PRADOS: Vincent Van Gogh's Childhood and Boyhood: A Psychological Enquiry

Documents and Reports, Book Reviews, Books Received

Subscriptions per volume ( 3 issues) $£ 6.50$ (U.S. $\$ 19.50$ )

Single issues and back numbers $\mathbf{f 2 . 2 5}$ (U.S. \$6.75)

Subscriptions and advertising enquiries should be sent to

BASIL BLACKWELL \& MOTT LTD. (JOURNALS DEPT.)

108 COWLEY ROAD,

OXFORD OX4 1JF, U.K.

\section{CAMBRIDGE JOURNALS}

Language in Society is one of 48 learned journals published by Cambridge University Press.

The 1974 descriptive catalogue of Cambridge journals with details of back volumes is available from the London and New York offices of the Press.

Cambridge journals may be ordered from a bookseller or direct from the publishers.

\section{Cambridge University Press}

Bentley House, 200 Euston Road, London, NW1 2DB

American Branch: 32 East 57th Street,

New York, N.Y. 10022 
CAMBRIDGE STUDIES IN LINGUISTICS 13

\section{The Social Differentiation of English in Norwich} PETER TRUDGILL

Dr Trudgill presents results from the first socio-linguistic urban dialect survey to be completed in Britain, and attempts to apply linguistic data gathered in the speech community to problems of linguistic theory. 'The final chapter, for example, discusses the implications of variable urban dialect data for theoretical phonology, and examines some of the ways in which linguistic variation can be dealt with by correct linguistics.

The book is by no means entirely theoretical. It contains an analysis of the different social class dialects and accents spoken in the city of Norwich, and gives illustrations of the way in which Norwich English has developed out of surrounding rural dialects. Dr Trudgill also examines some of the ways in which social pressures can lead to linguistic change, and the routes by which linguistic changes spread through a speech community. There is finally a discussion of the methodology of urban dialect surveys which will be useful to those who undertake this type of work in the future.

$£ 4.90$ net

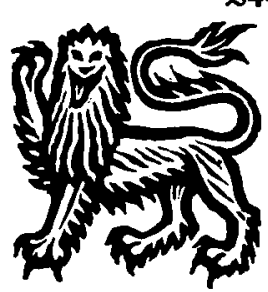

CAMBRIDGE UNIVERSITY PRESS 
Typescripts. The top copy of the typescript should be submitted and, if possible a second copy also. Contributions should be clearly typed on one side of the paper only using a conventional size of paper, preferably $\mathrm{A}_{4}$ (or 2 r. 6 by 28 centimeters for those at work where $\mathrm{A}_{4}$ is not available). Authors should hold one copy for the correction of proofs. The title-page should include the title, author's name and affiliation, in that order, along with an abstract of the article. Areas of study to which the articles may be of interest should be listed at the end of the abstract.

Titles should be so worded that the first part may be used as a running headline (with a maximum length of 50 characters, including spaces). They should be typed on a separate sheet, together with the author's name and the address to which he wishes proofs to be sent.

Citations and forms of emphasis. Normally the Latin alphabet is to be used. Cited forms should be underlined to represent italicization in print. Translational 'meanings' should be placed within single quotation marks.

References are to be made in the text (and not in footnotes) by giving in brackets the name of the author and year of publication, and where relevant the page(s) referred to; e.g. (Whitney r $867: 45-53$ ). If the author's name is part of the text, the following form should be used: 'Whitney (1867: 48) maintained that .... When a work written by two or more authors is referred to, all names should be given in the first citation; e.g. (Weinreich, Labov \& Herzog 1968): in subsequent citations the first name only should be given, with 'et al.' added; e.g. (Weinreich et al., 1968). When separate works are referred to in the same bracket, those by the same author should be separated by commas and those by different authors by semi-colons: e.g. (Whitney I867; Firth 1935, 1957a). Initials should be used (after the author's name) only when it is necessary to distinguish between two or more authors of the same name, all of whom are referred to in the same article.

All works referred to should be listed at the end of the article, double-spaced and in alphabetical order. The titles of articles should so far as possible be abbreviated according to the conventions of the
Linguistic Bibliography of the Permanent International Committee of Linguists (CIPL).

Examples of references (note the use of punctuation marks within references):

Firth, J. R. (1957a). Ethnographic analysis and language with reference to Malinowski's views. In R. W. Firth (ed.), Man and culture: an evaluation of the work of Bronislaw Malinowski. London: Routledge and Kegan Paul. 93-I I8.

— $(1957 b)$. A synopsis of linguistic theory, 1930-55. Studies in linguistic analysis (Special volume of the Philological Society). Oxford. I-33.

Sapir, E. (1929). The status of linguistics as a science. $\mathrm{Lg} . \mathbf{5}, 207-14$. (Reprinted in D. G. Mandelbaum (ed.). (1949) Selected writings of Edward Sapir. Berkeley and Los Angeles: U. California P. 160-6.)

Book reviews. With the exception of the title-page, book reviews should be submitted in the same form as articles. The title-page should take the following form: Edwin Ardener (ed.), Linguistics and Social Anthropology. (ASA Monographs, Io.) London: Tavistock, I97I.

Reviewed by Clive Criper

Department of Linguistics

University of Edinburgh

There is no need to submit an abstract with a book review.

Proofs. First proofs only will be sent to the author (or his nominee), who will be expected to correct them and return them to the Editor, by airmail where appropriate, within ten days of receipt.

Separates. Fifty separates of both articles and review articles will be provided free of charge. Additional separates may be obtained at reasonable cost, provided that these are ordered before publication on the special form sent out with the proofs.

Submission of an article is taken to imply that it has not previously been published, or is not being considered for publication elsewhere. If an author is publishing a related article alsewhere, this fact should be stated.

Copyright. Contributors of accepted articles will be asked to assign their copyrights, on certain conditions, to Cambridge University Press, to help protect their material, particularly in the U.S.A. 


\section{Lang. Soc. 3, I}

\section{Language in Society}

\section{Volume 3 Number I April 1974}

\section{Problems of choice in language change}

R. B. LE PAGE: Sociolinguistic survey of multilingual communities, Survey of Cayo District, British Honduras

J. v. NEUSTUPNÝ: The modernization of the Japanese system of communication

Sources of structure in ethnographic semantics

P. SEITEL: Haya metaphors for speech

REVIEWS

The state of sociolinguistic research

R. SHUY (ed.): Sociolinguistics: current trends and prospects (Akhmanova) 91

(Center for Applied Linguistics) Sociolinguistics: A cross disciplinary perspective (Halliday) 94

w. K. RILEY \& D. M. SMITH (eds.): Sociolinguistics (Bauman) joint review with:

D. M. SMITH \& R. SHUY (eds.): Sociolinguistics in cross cultural analysis (Bauman) $\quad$ I03

Sociolinguistics in the Federal Republic of Germany (Schröder) 109

Glossolalia

F. GOODMAN: Speaking in tongues: A cross cultural study of glossolalia (Wolfram)

W. SAMARIN: Tongues of men and angels: The religious language of Pentecostalism (Crystal) 126

Speech acquisition and education

C. B. CAZDEN: Child language and education (Turner)

D. I. SLoBIN: Leopold's bibliography of child language (Crystal) 135

C. B. CAZDEN, v. JOHN, \& D. HYMES (eds.): Functions of language in the classroom (Stubbs) I4I

S. M. ERVIN-TRIPP: Language acquisition and communicative choice (Giles) 145

Sociolinguistic research in Africa

C. SCOTTON: Choosing a lingua franca in an African capital (Cooper)

M. Houise: Anthropologie linguistique de l'Afrique Noire (Baucom)

Other:

D. sudnow (ed.): Studies in social interaction (Mehan)
(C) Cambridge University Press 1974

CAMBRIDGE UNIVERSITY PRESS

Bentley House, 200 Euston Road, London NWI 2DB

American Branch: 32 East 57th Street, New York, NY 10022

Single parts $£ 3.5 \circ$ net in UK (US $\$ 10.50$ in USA and Canada) Annual subscription $£ 5.5^{\circ}$ net in UK (US \$16.50 in USA and Canada)

\author{
Printed in Great Britain by
}

Alden \& Mowbray Ltd at the Alden Press, Oxford 